\title{
Urgensi Penjelasan Keagamaan terhadap Keluarga Suspek Pasien Dalam Pengawasan (PDP) Covid-19
}

\section{Asep Muhyiddin ${ }^{*}$, Rifki Rosyad ${ }^{2}$, M. Taufiq Rahman ${ }^{3}$, Yeni Huriani ${ }^{4}$}

1 Program Studi Doktoral Studi Agama-Agama, UIN Sunan Gunung Djati Bandung, Indonesia; e-mail: asep.muhyiddin@uinsgd.ac.id

2 Program Studi Magister Studi Agama-Agama, UIN Sunan Gunung Djati Bandung, Indonesia; e-mail: rifkirosyad@uinsgd.ac.id

3 Program Studi Magister Studi Agama-Agama, UIN Sunan Gunung Djati Bandung, Indonesia; e-mail: fikrakoe@uinsgd.ac.id

4 Program Studi Magister Studi Agama-Agama, UIN Sunan Gunung Djati Bandung, Indonesia; e-mail: yenihuriani@uinsgd.ac.id

* Correspondence

Received: 2020-04-27; Accepted: 2020-06-05; Published: 2020-06-25

\begin{abstract}
This study discusses religious explanations as a form of communication behavior among public relations officers at Pakuwon General Hospital, Sumedang. Here discussed how the adaptation of a hospital to the times, including an outbreak of a disease, such as Covid-19. With a qualitative approach and descriptive method, it is known that the hospital not only meets the health needs of patients, but also as a place of calm will be anxious about health problems. Due to the strong religious attitude, the religious explanation from the Public Relations also always accompanies the logic of explanation to patients, including about Covid-19. The need for existence is a major need during epidemics, where health and safety needs affect each other. The need for humanistic concern is the most important of the needs of interconnection; Interpersonal and family needs also increase. Here the religious explanation plays an important role because the society faced is also a religion-based society, namely Islam as the majority religion of Sumedang residents. It was found that the existence, linkages, and growth in clinical nurses need to coexist. Religious explanation is very helpful to meet the information needs so that communication between the hospital and the families of COVID-19 Patients Under Supervision (PDP) can be felt properly.
\end{abstract}

Keywords: psychological needs; health communication; hospital management; corona outbreak; religiousness.

\begin{abstract}
Penelitian ini membahas tentang penjelasan keagamaan sebagai bentuk perilaku komunikasi di kalangan pegawai humas Rumah Sakit Umum Pakuwon, Sumedang. Di sini dibahas bagaimana adaptasi sebuah rumah sakit terhadap perkembangan zaman, termasuk wabah suatu penyakit, seperti Covid-19. Dengan pendekatan kualitatif dan metode deskriptif, diketahui bahwa RS itu selain untuk memenuhi kebutuhan kesehatan pasiennya, tetapi juga sebagai tempat ketenangan akan suatu keresahan masalah kesehatan. Disebabkan sikap keberagamaan yang kental, maka penjelasan keagamaan dari pihak Humas pun selalu menyertai logika penjelasan pada pasien, termasuk tentang Covid-19. Kebutuhan keberadaan adalah kebutuhan utama selama epidemi, di mana kebutuhan kesehatan dan keamanan saling mempengaruhi. Kebutuhan keprihatinan humanistik adalah yang paling penting dari kebutuhan keterkaitan; kebutuhan interpersonal dan keluarga juga meningkat. Di sini penjelasan keagamaan memainkan peranan penting karena masyarakat yang dihadapi adalah juga masyarakat yang berbasis agama, yaitu agama Islam sebagai agama mayoritas warga Sumedang. Ditemukan bahwa keberadaan, keterkaitan, dan pertumbuhan dalam perawat klinis perlu hidup berdampingan. Penjelasan keagamaan sangat membantu untuk memenuhi kebutuhan informasi sehingga komunikasi antara pihak rumah sakit dengan keluarga Pasien Dalam Pengawasan (PDP) COVID-19 dapat dirasakan dengan baik.
\end{abstract}


Keywords: kebutuhan psikologis; komunikasi kesehatan; manajemen rumah sakit; wabah corona; keberagamaan.

\section{Pendahuluan}

Pada bulan Desember 2019, epidemi penyakit coronavirus 2019 (COVID-19) ditemukan di Wuhan, Provinsi Hubei, Cina (Liu et al., 2020). Virus ini sangat menular, tetapi sumber dan rute penularannya belum ditentukan (Yin \& Zeng, 2020). Sejak akhir 2019 coronavirus terus menyebar dan baru ditetapkan sebagai pandemic oleh WHO pada Maret 2020 (Cucinotta \& Vanelli, 2020)(Spinelli \& Pellino, 2020). Di Indonesia sendiri sudah mencapai 510 terinfeksi, 20 orang sembuh dan 38 meninggal dunia (Darsono, Rohmana, \& Busro, 2020).

Di Kabupaten Sumedang, Jawa Barat, pada saat ini, yang betul-betul positif menurut hasil pemeriksaan swab hanya empat orang, terakhir nambah dua orang jadi enam orang, satu orang sudah sembuh. Namun demikian Orang Dalam Pemantauan (OPD) dan Pasien Dalam Pengawasan (PDP) memang cukup banyak. Hampir 50an orang jumlah PDP dan 200an orang jumlah ODP. Guna menangani kasus tersebut, pemerintah Kabupaten Sumedang membuat Gugus Tugas Penanganan Kasus Virus Corona di Rumah Sakit Umum Daerah (RSUD) Sumedang. Rumah sakit lain dan lembaga kesehatan masyarakat lainnya seperti Pusat Kesehatan Masyarakat (Puskesmas) harus merujuk kepada RSUD Sumedang apabila ada kasus (Wawancara dengan FF, Direktur RSUP, 28 April 2020).

Namun demikian, yang terjadi di Rumah Sakit Umum Pakuwon (RSUP) sebagai rumah sakit swasta yang bukan rujukan kasus Corona, kecemasan tidak begitu saja reda. Para pekerja di rumah sakit tersebut mengalami stres besar ketika mereka berada di rumah sakit. Rumah sakit tersebut mendadak juga harus memenuhi kebutuhan kesehatan, keselamatan, hubungan interpersonal, dan pengetahuan terkait. Begitu juga halnya dengan pasien dan keluarga pasien, apalagi mereka yang dikategorikan sebagai Pasien Dalam Pengawasan (PDP). Dengan demikian, permasalahannya adalah bahwa keadaan genting seperti wabah corona ini telah menyebarkan rasa takut, waswas, dan cemas pada masyarakat. Ada kebutuhan untuk rasa aman di sini.

Alderfer (1969) mengajukan teori keberadaan, keterkaitan, dan pertumbuhan (Existence-RelationGrowth; ERG) kebutuhan humanistik berdasarkan hierarki kebutuhan Maslow. Dia percaya bahwa orang memiliki tiga kebutuhan inti, yaitu kebutuhan untuk bertahan hidup, kebutuhan untuk menjalin hubungan, dan kebutuhan untuk pertumbuhan dan perkembangan. Tujuan dari penelitian ini adalah untuk menggunakan wawancara mendalam untuk memahami pola komunikasi yang berbasis keagamaan untuk menjelaskan perihal penanganan dan pencegahan covid-19 dari pihak rumah sakit yang mengandalkan tenaga humas, perawat, dan dokter. Sementara itu, kebutuhan psikologis pihak rumah sakit sendiri dalam situasi epidemi yang luar biasa ini cukup membuat stres. Kajian ini menganalisis konten utama kebutuhan psikologis mereka dari kacamata teori ERG dan untuk memberikan perspektif untuk intervensi untuk mengurangi tekanan psikologis pasien, keluarga pasien, dan perawat di garis depan.

Selama ini sumber pengetahuan mengenai rumah sakit berpusat pada humas. Sebelum wabah corona ini, lembaga Humas RSU Pakuwon sering disepelekan, baik di tingkat internal maupun ekternal (Sjoraida \& Anwar, 2018). Memang, Humas dianggap hanya bertugas untuk melaksanakan konferensi pers dan atau mengirimkan siaran pers, padahal Humas juga mempunyai tugas untuk mengadakan komunikasi ke dalam (employee relation atau internal communication), yang juga bertujuan mendapatkan dukungan dan pengertian dari bawah terhadap usaha-usaha organisasi. Humas pun harus mampu memberikan saran kepada pimpinan untuk merumuskan kebijaksanaan, dan menumbuhkan good will yang baik terhadap citra organisasi (Epstein, 2018). Oleh karena itu perlu disadari pengertian tentang apa yang dapat dilakukan oleh Humas bagi pimpinan rumah sakit (Dewan Direksi) dan organisasi rumah sakit sendiri, yaitu bagaimana memproyeksikan pesan yang tepat ke pengguna melalui penguasaan komunikasi, melakukan kegiatan promosi efektif sesuai biaya yang tersedia, dan memanfaatkannya sebagai alat manajemen yang baik (Manners, 2017). 
Namun demikian, dengan adanya pandemi corona ini, humas menjadi lembaga yang sangat penting. Humas harus dengan lincah memberi penjelasan ke berbagai pihak baik internal maupun eksternal. Walaupun penting, tetapi petugasnya biasanya sedikit saja. Di RSUP sendiri biasanya Humas digandengkan dengan Pemasaran dan berada di bawah Bagian Umum (Rumah Sakit Umum Pakuwon, 2017), kini harus bergandengan tangan dengan para perawat dan dokter yang berhadapan langsung dengan pasien dan keluarga pasien. Selama wabah corona ini, Humas RSUP telah berperan melalui beberapa kegiatan yang menunjang kegiatan manajemen dalam mencapai tujuan organisasi; membina hubungan harmonis antara organisasi dengan publik, baik publik eksternal maupun publik internal; menciptakan komunikasi dua arah timbal balik dengan menyebarkan informasi dari organisasi kepada publik dan menyalurkan opini publik kepada organisasi. Hal tersebut dapat terlihat dalam sasaran mutu yang disampaikan pada bagian sebelumnya sehingga diharapkan strategi humas dan proses pemasaran untuk mencapai pelanggan yang potensial dapat tercapai. Dalam hal ini pihak Humas RSUP melakukan komunikasi dua arah dengan publik rumah sakit melalui media sosial seperti facebook, twitter, Instagram, dan WhatsApp Group (Wawancara dengan IR, Kepala Humas RSUP, 2 April 2020).

Namun demikian, dengan adanya wabah corona ini, kini masyarakat ingin langsung mendapatkan jawaban dari berbagai pertanyaan yang dipikirkannya, termasuk tentang kesehatan dirinya. Seringkali pihak pasien, termasuk keluarganya, datang ke rumah sakit dalam keadaan panik. Di sini harus segera dilakukan komunikasi yang tepat agar dapat meredakan berbagai ketegangan yang terjadi karena ketakutan atas keberadaan virus corona tersebut (Wawancara dengan FF, Direktur RSUP, 28 April 2020). Hal inilah yang akan dibahas pada bagian berikutnya dari tulisan ini.

\section{Metode Penelitian}

Data yang digunakan dalam penelitian ini merupakan data kualitatif dengan jenis penelitian deskriptif. Data penelitian ini merupakan data primer yaitu sumber data penelitian yang diperoleh peneliti secara langsung dari objek penelitian dan data sekunder, yaitu sumber data penelitian yang diperoleh peneliti secara tidak langsung melalui media perantara (Roth \& Rosenzweig, 2020).

Pengumpulan data dilakukan pada bulan April 2020. Dalam penelitian ini, metode purposive sampling digunakan untuk memilih responden dari rumah sakit umum sekunder di Sumedang yang telah merawat pasien dengan COVID-19. Kriteria inklusi: pasien PDP, keluarga pasien PDP, perawat terdaftar di garis depan; pegawai humas, dokter, dan direktur; semuanya partisipasi sukarela dalam penelitian ini. Sebanyak 10 responden diwawancarai; ukuran sampel didasarkan pada saturasi informasi (Guo, Lu, Kuang, \& Wang, 2020). Di antara perawat yang diwawancarai, empat adalah perempuan dan satu laki-laki, berusia 25-38 $(29,9 \pm 3,62)$ tahun. Satu dari mereka memiliki pengalaman keperawatan 5 tahun atau kurang, dua memiliki 5-10 tahun pengalaman keperawatan, dan dua memiliki 10 atau lebih tahun pengalaman keperawatan. Kemudian diwawancarai pula satu orang pasien, satu orang keluarga pasien, satu orang pegawai humas, satu orang dokter, dan satu orang direktur.

Penelitian ini menggunakan metode wawancara semi-terstruktur, pribadi, dan mendalam. Garis besar wawancara dirumuskan berdasarkan format wawancara dari tinjauan literatur sebelumnya. Garis besar wawancara adalah sebagai berikut: (1) Tolong beritahu cara Anda menjelaskan pada PDP (Pasien Dalam Pengawasan) COVID-19 selama beberapa hari terakhir dan keluarganya? (2) Apa kebutuhan atau harapan terbesar mererka saat ini? (3) Apakah keberadaan PDP COVID-19 ke rumah sakit ini memengaruhi kunjungan ke rumah sakit ini? (4) Apakah Anda memasukkan penjelasan keagamaan dalam penjelasan terhadap pasien dan keluarga pasien? Bagaimana tanggapan mereka?

Wawancara dilakukan oleh para peneliti yang telah dilatih dalam teknik wawancara penelitian kualitatif. Sebelum wawancara, orang yang diwawancarai diberitahu tentang tujuan, isi, dan pentingnya penelitian ini untuk mendapatkan kepercayaan dan kerja sama mereka. Wawancara dilakukan di ruangan yang tenang dan berventilasi baik, yang akan didesinfeksi setelah menyelesaikan wawancara. Baik pewawancara dan orang yang diwawancarai mengenakan topeng pelindung dengan 
jarak setidaknya 1 meter dari satu sama lain, dan durasi waktu wawancara disimpan dalam 30 menit sebanyak mungkin. Perekam suara digunakan untuk merekam selama wawancara dengan persetujuan dari orang yang diwawancarai. Selain itu, isyarat non-verbal oleh orang yang diwawancarai, seperti gerakan mata dan gestur, diperhatikan dan dicatat. Orang yang diwawancarai diberi kode R1 - R10 ( $R=$ Responden) dan privasi mereka dilindungi sesuai dengan prinsip kerahasiaan (Surmiak, 2018). Penelitian ini disetujui oleh komite etika rumah sakit Pakuwon.

Dalam waktu 24 jam setelah setiap wawancara, para peneliti dengan hati-hati membaca catatan wawancara dan menyalin catatan wawancara dengan kata demi kata di bawah ingatan adegan wawancara. Metode analisis kategori digunakan untuk mengklasifikasikan data dengan atribut yang sama menjadi tema dan nama diberikan kepadanya. Berdasarkan pengodean teks wawancara, jumlah individu yang awalnya menyebutkan setiap pengodean dan berapa kali disebutkan dihitung. Pengkodean utama kemudian diekstraksi dan diintegrasikan untuk membentuk sistem pengkodean. Akhirnya, kami mengekstraksi konten utama dari penjelasan keagamaan pihak rumah sakit dari sistem pengkodean berdasarkan teori ERG.

\section{Hasil dan Pembahasan}

Rumah Sakit Umum Pakuwon (RSUP) dioperasikan sejak tahun 1999 di Sumedang. Semula rumah sakit ini dikhususkan pada pelayanan kasus-kasus bedah saja, akan tetapi meliat desakan dan animo masyarakat yang datang tidak hanya dengan kasus bedah saja, akhirnya berubah menjadi rumah sakit umum pada tahun 2001. Rumah sakit swasta ini kemudian mendapatkan status sebagai perseroan terbatas (PT) pada tahun 2012 dan pada tahun 2016 mendapatkan Akreditasi menjadi Rumah Sakit Kelas C (Rumah Sakit Umum Pakuwon, 2017).

\section{Ringkasan kebutuhan psikologis}

Pengkodean dan analisis data wawancara menunjukkan bahwa, dari sudut pandang teori ERG, di antara kebutuhan psikologis pasien dan keluarga pasien, kebutuhan keberadaan terutama diwujudkan sebagai kebutuhan untuk kesehatan dan keselamatan. Kebutuhan akan kesehatan mengacu pada perhatian perawat terhadap kesehatan fisik dan mental mereka sendiri, dan kebutuhan akan keselamatan mengacu pada harapan akan Alat Pelindung Diri (APD) yang memadai dan stabilitas emosional anggota pasien dan keluarga pasien. Kebutuhan keterkaitan terutama diwujudkan sebagai kebutuhan untuk hubungan antarpribadi, kebutuhan untuk perhatian masyarakat, dan kebutuhan untuk kasih sayang. Semuanya dikembalikan kepada agama dengan cara kesabaran dan ketaatan pada Tuhan. Selama masa pemeriksaan di rumah sakit, kebutuhan akan hubungan interpersonal secara khusus mencerminkan keinginan perawat klinis untuk berkomunikasi tatap muka dengan anggota keluarga, kolega, dan teman. Kebutuhan akan kepedulian masyarakat terwujud sebagai kebutuhan perawat untuk perawatan, bantuan, dan dukungan dari kepala departemen, rumah sakit, dan dunia luar. Kebutuhan akan kasih sayang mencerminkan keinginan mereka untuk kasih sayang lebih kuat dari biasanya kepada sesama manusia, terutama pasien dan keluarganya. Kebutuhan pertumbuhan dimanifestasikan sebagai kebutuhan yang kuat untuk pengetahuan tentang pencegahan dan kontrol COVID-19, terutama dari laporan otoritatif.

Penjelasan dan contoh spesifik dari kategori

Keberadaan, keterkaitan, dan kebutuhan pertumbuhan

Analisis kami menunjukkan bahwa $80 \%$ responden menunjukkan adanya, keterkaitan, dan kebutuhan pertumbuhan, dan ketiga kebutuhan ini saling memengaruhi.

Sebagai perawat, R1 (Wawasancara, 4 April 2020) seringkali menyatakan kepada pasien suspek PDP: "Saya berharap sistem kekebalan tubuh Anda sendiri dapat menghilangkan virus." Demikian itu 
merupakan langkah awal untuk menenangkan pasien dan keluarga pasien yang membawanya. R1 mengakui bahwa "Ada terlalu banyak informasi tentang COVID-19 setiap hari. Sebagian besar adalah rumor, dan saya berharap ada lebih banyak laporan resmi dari pihak berwenang."

Sebagai perawat, R4 (Wawasancara, 7 April 2020)berharap: "Saya harap Anda tidak akan terinfeksi oleh virus."; "Aku merindukan hari-hari ketika kita bisa berbicara satu sama lain tanpa masker wajah"; "Saya harap para ilmuwan dapat menemukan sumber infeksi dan mengembangkan vaksin sesegera mungkin."

Sebagai pegawai humas, R8 (Wawasancara, 4 April 2020)mengemukakan: "Saya berharap bahwa pemerintah terus menerus melakukan kampanye cara melawan wabah, karena kami cukup kewalahan dengan berbagai pertanyaan; walaupun kami sendiri banyak melakukan penjelasan di berbagai media baik itu media mainstream maupun media sosial."

Sebagai direktur, R10 (Wawasancara, 4 April 2020) menyatakan: "Ada kekurangan peralatan perlindungan pribadi di rumah sakit ini saat ini. Virus masih belum dapat diobati dengan obat-obatan tertentu. Saya merasa sangat cemas dan takut." Jelas bahwa sebagian besar yang diwawancarai memiliki keberadaan, keterkaitan, dan kebutuhan pertumbuhan secara bersamaan, dan efek yang berinteraksi ditemukan di antara kebutuhan ini. Ketika salah satu dari kebutuhan ini terpenuhi dengan baik, yang lain dapat diredakan.

\section{Kebutuhan akan keberadaan saat ini}

Wawancara menunjukkan bahwa kebutuhan akan keberadaan saat ini adalah kebutuhan utama di rumah sakit. Kesehatan fisik adalah kebutuhan dasar yang diperlukan untuk mengatasi epidemi, dan semua responden menunjukkan kebutuhan yang kuat untuk menjaga kesehatan.

Sebagai perawat, R2 (Wawasancara, 9 April 2020) menyatakan: "Sekarang, saya makan buah dan mengonsumsi suplemen vitamin $C$ setiap hari untuk memperkuat kekebalan saya."

Perawat lain, R5, juga cukup banyak berusaha dan berdo'a: "Saya sekarang rajin berdo'a dan melakukan senam setiap hari di rumah, ikuti panduan di TV untuk menghilangkan racun dan memperkuat kekebalan saya. Sekarang saatnya bekerja keras untuk membangun kekebalan saya."

Sebagai pasien, R6 (Wawasancara, 7 April 2020)menyatakan: "Saya merasa badan terasa flu dan pegalpegal, tapi saya kira bukan corona. Saya pikir memiliki lebih banyak sup ayam dapat mengurangi beberapa gejala flu biasa. Sekarang saya makan banyak setiap hari."

Juga ditemukan bahwa kebutuhan untuk kesehatan dan keselamatan di antara perawat klinis berinteraksi satu sama lain; ketika kebutuhan akan keselamatan terpenuhi, kebutuhan akan kesehatan dapat menurun. Ketika ditanya tentang kebutuhan atau harapan terbesar saat ini untuk perawat klinis, baik R3 (Wawasancara, 4 April 2020) maupun R5 (Wawasancara, 4 April 2020) menjawab: "Baru-baru ini saya melihat laporan berita bahwa aliran terus-menerus peralatan pelindung diri dikirim ke berbagai rumah sakit, dan saya merasa kurang khawatir [tentang kesehatan saya]."

Sebagai keluarga pasien, R7 (Wawasancara, 4 April 2020) menjelaskan: "Meskipun virus dapat bertahan hidup di udara selama beberapa waktu, saya tidak terlalu khawatir terkena infeksi selama saya memakai masker, memiliki udara segar, dan melakukan tindakan pencegahan keamanan yang tepat."

Kebutuhan akan kepedulian masyarakat

Melalui pengkodean dan analisis, ini menunjukkan bahwa kebutuhan akan kepedulian masyarakat adalah yang terpenting di antara kebutuhan hubungan (relationship). Semua yang diwawancarai menekankan perlunya kepedulian masyarakat, berharap untuk mendapatkan perawatan, bantuan, dan dukungan dari para pejabat dan rumah sakit, dan dunia luar.

Sebagai pasien, R6 (Wawasancara, 4 April 2020) menyatakan: “Sejujurnya, saya sangat khawatir sebelum datang ke rumah sakit ini, tetapi pada hari pertama di sini, kepala perawat secara pribadi menjelaskan pengetahuan yang relevan seperti desinfeksi dan karantina, dan itu banyak membantu saya untuk tenang. Lebihlebih para perawat selalu mengingatkan bahwa wabah ini adalah ujian dari Tuhan."

Sebagai keluarga pasien, R7 (Wawasancara, 4 April 2020) menyatakan: "Saya harap rumah sakit membentuk gugus tugas dukungan psikologis untuk meredakan ketegangan dan ketakutan kita." 
Sebagai perawat, R4 (Wawasancara, 4 April 2020) menyatakan: "Saya harap masyarakat dan pemerintah kita lebih memperhatikan kurangnya peralatan perlindungan pribadi." 80\% dari orang yang diwawancarai menunjukkan kebutuhan untuk hubungan interpersonal dan kasih sayang. Karena dampak epidemi, kebutuhan untuk hubungan interpersonal dan kasih sayang sementara ditekan, sehingga menyebabkan kebutuhan ini meningkat terus menerus.

Sebagai perawat, R2 (Wawasancara, 4 April 2020) memang mengakui: "Sekarang, saya langsung pergi ke kosan saya setelah bekerja setiap hari. Saya tidak bisa melihat keluarga saya atau pergi berbelanja dengan teman saya. Saya harap kami mengatasi epidemi dan kembali ke kehidupan normal sesegera mungkin." Namun dia juga mengembalikan semuanya pada Tuhan dengan harapan semoga Tuhan mengangkat penyakit ini dari bumi.

Sebagai seorang dokter, R9 (Wawasancara, 4 April 2020) menyatakan: "Di masa lalu, bukan masalah besar ketika semua orang bekerja bersama. Sekarang semua orang perlu memakai alat pelindung diri untuk menghindari infeksi silang. Setiap orang takut untuk sering keluar rumah setelah bekerja. Aku merindukan harihari ketika kita bisa berbicara dan tertawa bersama."

Sebagai seorang perawat, R5 (Wawasancara, 4 April 2020) menegaskan: "Saya harap saya bisa mengatasi kecemasan saya. Karena hal itu akan berefleksi terhadap para pasien, termasuk pasien umum. Demikian karena rumah sakit ini bukan rumah sakit rujukan corona. Jadi kami buka untuk pasien umum. Tapi begitulah, ketakutan itu muncul, apalagi ada pasien yang menderita ispa, takut itu corona. Tapi kita harus memperlihatkan ketegaran pada pasien dan keluarga pasien sambil kita pun hati-hati dengan memakai APD. Jadi pasien dan keluarganya juga tenang. Apalagi dengan penjelasan yang bersifat keagamaan, mereka akhirnya menjadi sabar.

Sebagai keluarga pasien, R7 (Wawasancara, 4 April 2020) menyatakan: "Saya dengar udah ada kasus yang terinfeksi di Sumedang. Saya takut keluarga saya ini juga, karena pulang dari Jakarta. Saya harap sih tidak."

Sebagai seorang dokter, R9 (Wawasancara, 4 April 2020) menegaskan: "Saya selalu menjelaskan pada pasien dan seisi rumah sakit yang bertanya, bahwa ini adalah sejenis flu, seperti flu biasa. Dulu juga ada flu burung dan flu babi. Jadi sudah biasa. Yang meninggal karena kasus lain, seperti demam berdarah itu lebih banyak. Jadi tenang saja. Semua sedang ditangani. Berdo'a saja pada Allah."

Kebutuhan akan pengetahuan

Karena wabah saat ini disebabkan oleh virus corona baru yang belum pernah ditemukan pada manusia sebelumnya, pengetahuan tentang virus itu sendiri dan penyakit yang ditimbulkannya masih dalam penyelidikan terus-menerus. Wawancara kami menunjukkan bahwa perawat klinis memiliki kebutuhan yang kuat untuk pengetahuan tentang virus corona baru yang memenuhi kebutuhan psikologis mereka sendiri, yang kemudian dapat disebarkan kepada yang lain terutama pasien dan keluarga pasien. Sekitar $90 \%$ responden mengatakan bahwa mereka ingin tahu lebih banyak tentang virus corona.

Sebagai seorang perawat, R1 (Wawasancara, 4 April 2020) menyatakan: "Saya berharap dapat mengurangi ketakutan saya sendiri dengan mengetahui lebih banyak informasi yang benar tentang virus ini."

Selain itu, perawat lain, R2 (Wawasancara, 4 April 2020) menegaskan: "Karena saya tidak bisa bertemu dengan kolega, teman, atau kerabat saya setiap hari, pada dasarnya saya menghabiskan waktu luang menjelajahi web, berharap mendapatkan informasi yang berguna tentang pencegahan pneumonia virus korona terbaru."

Perawat lain, R5 (Wawasancara, 4 April 2020) menyatakan: "Sebetulnya kalau kita mengup-date pengetahuan dari sumber yang dapat dipercaya seperti dari jurnal-jurnal, kita tidak akan banyak sesat menyesatkan."

Sebagai seorang dokter, R9 (Wawasancara, 4 April 2020) menganalisis: "Saya melihat beberapa ratus kasus baru yang dikonfirmasi setiap hari, dan saya merasa panik, tetapi melihat bahwa para peneliti telah mengembangkan alat diagnostik, saya merasa bahwa kami tidak jauh dari mengatasi epidemi."

Penjelasan Keagamaan terhadap Keluarga Suspek Pasien Dalam Pengawasan (PDP) Covid-19 
Kebutuhan psikologis perawat yang merawat pasien COVID-19 diselidiki dari perspektif teori ERG. Ditemukan bahwa kebutuhan untuk keberadaan, keterkaitan, dan pertumbuhan hidup berdampingan antara pihak rumah sakit dan pihak pasien saling mempengaruhi. Ini juga konsisten dengan gagasan yang diajukan oleh teori ERG bahwa "seorang individu mungkin memiliki lebih dari satu kebutuhan pada saat yang sama" (Crews \& Russ, 2020). Wawancara menunjukkan bahwa orangorang rumah sakit dan pasien serta keluarganya memiliki kebutuhan pada tingkat yang berbeda. Ini konsisten dengan gagasan bahwa "Sekalipun kebutuhan seseorang akan keberadaan dan keterkaitan belum terpenuhi sepenuhnya, ia masih dapat berupaya mengembangkan kebutuhan untuk pertumbuhan", sebagaimana dinyatakan oleh teori ERG (Alderfer, 1969).

Meskipun saat ini tidak ada obat atau vaksin spesifik yang efektif melawan COVID-19, kemungkinan infeksi dapat dikurangi dengan mengikuti langkah-langkah perlindungan ilmiah (Dhama et al., 2020). Saat ini, agen pemerintah dan manajer rumah sakit berusaha keras untuk mengumpulkan dan mendistribusikan peralatan perlindungan pribadi untuk memastikan kebutuhan keamanan garis depan. Persediaan yang memadai, pemanfaatan peralatan perlindungan pribadi secara ilmiah dan wajar akan memenuhi kebutuhan kesehatan dan keselamatan di antara orang-orang yang bekerja di rumah sakit. Kelengkapan peralatan ini dapat menjadi sumber ketenanganan bagi pasien dan keluarga pasien.

Wawancara menunjukkan bahwa kepedulian kemanusiaan dari masyarakat terhadap orangorang yang bekerja di rumah sakit diperlukan, terutama dalam keadaan luar biasa selama epidemi. Sehingga masyarakat tidak usah terlalu panik dan ingin didahulukan dalam pelayanan dan sebagainya. Membentuk gugus tugas penanggulangan psikologis dengan bantuan Komite Medik, humas dan psikolog, dan menyiapkan platform dukungan psikologis untuk memberikan dukungan masyarakat bagi para profesional kesehatan, dapat berkontribusi untuk memenuhi kebutuhan pihak rumah sakit dalam melindungi kesehatan mental para pekerja. Pada gilirannya, pihak rumah sakit pun dapat menjelaskan keberadaan penyakit virus corona di rumah sakit dan pencegahannya di luar rumah sakit kepada pasien dan keluarga mereka dengan tenang, tanpa ketakutan dan kecemasan.

Wawancara juga menunjukkan bahwa meskipun komunikasi tatap muka berkurang selama epidemi, kebutuhan untuk hubungan interpersonal dan kasih sayang pada perawat klinis dapat ditingkatkan melalui cara-cara lain untuk ekspresi emosional, seperti rekan kerja yang saling mendukung selama shift kerja, menulis do'a pada APD, menikmati makan siang yang disediakan oleh relawan sosial, dan sebagainya. Yang paling penting adalah bahwa semuanya dilakukan dengan kesadaran sebagai sama-sama makhluk Tuhan, yang kerdil, yang harus saling menyayangi, dan saling menolong. Penjelasan-penjelasan keagamaan seperti inilah yang dapat diterima di masyarakat Kabupaten Sumedang, yang notabene religius dan berbudaya.

Wawancara menunjukkan bahwa orang-orang yang bekerja di rumah sakit memiliki kebutuhan yang kuat untuk pengetahuan, yang dapat membawa kurangnya kecemasan. Ini juga konsisten dengan konsep "frustrasi-regresi" yang diusulkan dalam teori ERG, yang menyatakan bahwa ketika kebutuhan tingkat yang lebih tinggi tidak terpenuhi, kebutuhan tingkat yang lebih rendah dapat ditingkatkan sebagai pengganti. Oleh karena itu, pelatihan pengetahuan tentang pencegahan dan pengendalian COVID-19 akan membantu mengurangi kepanikan dan ketidakamanan psikologis yang disebabkan oleh pengetahuan yang tidak memadai (Darmawan, Miharja, Waluyajati, \& Isnaeniah, 2020). Penjelasan keagamaan sampai saat ini masih merupakan yang dominan harus terus diperkuat sejalan dengan keampuhannya menenangkan situasi di rumah sakit, baik itu untuk para pekerja maupun pengunjung (sebagai pasien ataupun keluarganya).

\section{Simpulan}

Selama situasi epidemi yang luar biasa, kebutuhan akan keberadaan, keterkaitan, dan pertumbuhan hidup berdampingan di antara perawat klinis dan saling mempengaruhi. Hal itu terutama tercermin dalam kebutuhan kesehatan dan keamanan, sedangkan kebutuhan keterkaitan (relationship) terutama terdiri dari kebutuhan antarpribadi, perhatian humanistik, dan kebutuhan keluarga; lebih jauh, kebutuhan pertumbuhan terutama terdiri dari kebutuhan pengetahuan. Lebih 
banyak perhatian harus diberikan pada kebutuhan para pekerja rumah sakit untuk melindungi kesehatan mereka. Hal ini membawa rasa aman bagi semua pihak terutama pada pasien dan keluarga pasien, terutama Pasien Dalam Pengawasan (PDP). Pengetahuan tentang pandemi koronavirus (COVID-19) dan cara-cara mencegah dan mengatasinya masih berkembang dan terus ditingkatkan, termasuk di rumah sakit sendiri seperti perawat, petugas humas, dokter dan bahkan direktur sendiri. Tetapi dengan optimisme dan penjelasan keagamaan, semua pihak bisa teredakan kepanikannya sehingga penanganan kasus corona di rumah sakit sekunder seperti Pakuwon itu berjalan dengan disertai ketenangan.

\section{Referensi}

Alderfer, C. P. (1969). An empirical test of a new theory of human needs. Organizational Behavior and Human Performance, 4(2), 142-175.

Crews, D. E., \& Russ, M. J. (2020). The impact of individual differences on multitasking ability. International Journal of Productivity and Performance Management.

Cucinotta, D., \& Vanelli, M. (2020). WHO declares COVID-19 a pandemic. Acta Bio-Medica: Atenei Parmensis, 91(1), $157-160$.

Darmawan, D., Miharja, D., Waluyajati, R. S. R., \& Isnaeniah, E. (2020). Sikap Keberagamaan Masyarakat Menghadapi Wabah COVID-19. Religious: Jurnal Studi Agama-Agama Dan Lintas Budaya, 4(2), 115-124.

Darsono, D., Rohmana, J. A., \& Busro, B. (2020). Against COVID-19 Pandemic: Bibliometric Assessment of World Scholars' International Publications related to COVID-19. Jurnal Komunikasi Ikatan Sarjana Komunikasi Indonesia, 5(1).

Dhama, K., Sharun, K., Tiwari, R., Dadar, M., Malik, Y. S., Singh, K. P., \& Chaicumpa, W. (2020). COVID-19, an emerging coronavirus infection: advances and prospects in designing and developing vaccines, immunotherapeutics, and therapeutics. Human Vaccines \& Immunotherapeutics, 1-7.

Epstein, M. J. (2018). Making sustainability work: Best practices in managing and measuring corporate social, environmental and economic impacts. London: Routledge.

Guo, Y., Lu, Z., Kuang, H., \& Wang, C. (2020). Information avoidance behavior on social network sites: Information irrelevance, overload, and the moderating role of time pressure. International Journal of Information Management, 102067.

Liu, W., Tao, Z.-W., Wang, L., Yuan, M.-L., Liu, K., Zhou, L., ... Liu, H.-G. (2020). Analysis of factors associated with disease outcomes in hospitalized patients with 2019 novel coronavirus disease. Chinese Medical Journal.

Manners, R. A. (2017). Professional dominance: The social structure of medical care. London: Routledge.

Roth, A., \& Rosenzweig, E. (2020). Advancing Empirical Science in Operations Management Research: A Clarion Call to Action. Manufacturing \& Service Operations Management.

Rumah Sakit Umum Pakuwon. (2017). Laporan Tahunan RSUP (Rumah Sakit Umum Pakuwon). Sumedang: Rumah Sakit Umum Pakuwon.

Sjoraida, D. F., \& Anwar, R. K. (2018). Pola Komunikasi Rumah Sakit di Era Digital. Jurnal Socio-Politica, 8(2), 148154.

Spinelli, A., \& Pellino, G. (2020). COVID-19 pandemic: perspectives on an unfolding crisis. The British Journal of Surgery.

Surmiak, A. D. (2018). Confidentiality in qualitative research involving vulnerable participants: Researchers' perspectives. Forum Qualitative Sozialforschung/Forum: Qualitative Social Research, 19(3).

Yin, X., \& Zeng, L. (2020). A study on the psychological needs of nurses caring for patients with coronavirus disease 2019 from the perspective of the existence, relatedness, and growth theory. International Journal of Nursing Sciences.

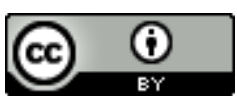

(C) 2020 by the authors. Submitted for possible open access publication under the terms and conditions of the Creative Commons Attribution 4.0 International (CC BY 4.0) license (https://creativecommons.org/licenses/by/4.0/). 